\title{
Watching Time: James Baldwin and Malcolm X
}

\author{
Mikko Tuhkanen Texas A\&M University
}

\begin{abstract}
Taking its cue from recent scholarly work on the concept of time in AfricanAmerican literature, this essay argues that, while both James Baldwin and Malcolm X refuse gradualism and insist on "the now" as the moment of civil rights' fulfillment, Baldwin also remains troubled by the narrowness assumed by a life, politics, or ethics limited to the present moment. In his engagement with Malcolm's life and legacy-most notably in One Day, When I Was Lost, his screen adaptation of Malcolm's autobiography-he works toward a temporal mode that would be both punctual and expansive. What he proposes as the operative time of chronoethics is an "untimely now": he seeks to replace Malcolm's unyielding punctuality with a different nowness, one that rejects both calls for "patience," endemic to any politics that rests on the Enlightenment notion of "perfectibility," and the breathless urgency that prevents the subject from seeing anything beyond the oppressive system he wants overthrown. Both thinkers find the promise of such untimeliness in their sojourns beyond the United States.
\end{abstract}

Keywords: James Baldwin, Malcolm X, One Day, When I Was Lost, The Autobiography of Malcolm X, Civil Rights movement, chronoethics, witnessing

Time is flying so fast, I know, now, we'll never catch up.

James Baldwin, Just Above My Head

Early on in the late novel Just Above My Head (1979), James Baldwin hangs "a pencil portrait of Malcolm X" under a clock behind the counter of a Harlem joint. ${ }^{1}$ It is in this bar that the novel's narrator, Hall Montana, meets his ex-girlfriend Martha after his deployment in Korea, several hundred pages later. Martha, we learn, is dating the bartender, Sidney. But her real news concerns the change that

James Baldwin Review, Volume 2, 2016 @ The Authors. Published by Manchester University Press and The University of Manchester Library 
this relationship has occasioned in her. She tells Hall that Sidney's incarcerated brother has studied Islam and pledged allegiance to "the Messenger from Allah"; Sidney - who has quit conking his hair-and Martha have followed suit, becoming converts. ${ }^{2}$ At stake is nothing less than a reorganization of reality, one that, as frequently happens in conversion narratives, is experienced as an awakening, the shedding of dreams. "I began to see that I'd been dreaming," Martha recounts, “... . [but] the dreamer awoke."'3

Although Malcolm's name occurs only once in the subsequent narrative, ${ }^{4}$ Martha and Sidney's epiphany is meant to recall his conversion to Islam in prison in 1952. Baldwin evokes Malcolm not only by having Sidney reject hair-straightening as part of the beauty regime with which Detroit Red courts whiteness, with painful results, in the famously tragicomic scenes of Malcolm's autobiography; ${ }^{5}$ it is also in their intensified time-consciousness that Martha and Sidney's awakening recalls Malcolm's. The converts' reordering of reality entails-as is, again, often the case in conversion narratives-a new chrononomy, a new method of reckoning time. Baldwin not only lets events unfold before the timekeeper and hand-drawn portrait, but time's pressing urgency is also felt in the frequent glances Martha steals at her watch as she speaks of her spiritual rebirth. ${ }^{6}$ "'Time will tell," Sidney asserts; time's will be the last word in history's unfolding. ${ }^{7}$

Baldwin was famously ambivalent about the Nation of Islam (NOI), under whose auspices Malcolm thrived in his early political career. Hall Montana is similarly skeptical about his friends' conversion, even if he does agree to lend an ear to "this Muslim shit."' Indeed, what Martha and Sidney experience as their awakening may merely mark the converts' shift from one oneiric realm to another. As Malcolm, having broken with NOI, tells a friend in 1964: "My mind was closed when I was under Elijah Muhammad's influence. I was like a sleepwalker for twelve years, but my mind's wide awake now."' In The Fire Next Time (1963), Baldwin similarly writes of what he considers NOI's uncreative reversal of white supremacist ideology: "The dream, the sentiment is old, only the color is new." ${ }^{10}$ The agents of one's coming-to-consciousness may but extend his mesmeric control, a spell where one is paralyzed by the enemy in the mirror. Contrary to appearances, the dream continues unbroken.

Yet, as is evident from Just Above My Head, what would have arrested Baldwin's attention in the difference that NOI made to lives such as Malcolm's is the temporal dimension of the conversion. He would have recognized here a familiar theme, for a philosophy of time plays a central role in all of his ethico-political thought. For Baldwin, in a world of finitude, time's passing issues an ethical demand, a call to responsibility that, as he insists, has gone unheeded in the modern world. As he writes in 1960, "most people in this country have yet to discover ... that time is real"; ${ }^{11}$ most people refuse the mode of ethics that the brevity of human life requires. The heedlessness toward time has produced what Baldwin frequently calls the "irreality" of life in the United States.

For Baldwin, the challenge that alienates Malcolm Little from diasporic modernity's familial genealogies into the absence-but also the crossroads, the 
buried treasure, "a certain dangerous potency"12_-signed by the $\mathrm{X}$ is a temporal one. Some ten years before writing what was to become his final novel, in One Day, When I Was Lost (written in 1968, publ. 1972), the screen adaptation of Malcolm's and Alex Haley's The Autobiography of Malcolm X (1965), he highlights the ways in which Malcolm's new life begins with the call of a different time and proceeds as a practice of temporal discipline. ${ }^{13}$ Malcolm, like Martha, keeps track of time. It is also in One Day, When I Was Lost that we arguably find a younger version of Just Above My Head's Sidney: like his namesake in the later novel, the young man who makes a brief but-as I will argue_crucial appearance in the screenplay is an avid witness to time.

Malcolm, Martha, and the two Sidneys are among a cast of characters with whom Baldwin renegotiates ethico-temporal imperatives in his art. This negotiation enters a crisis around Malcolm's assassination in the mid-1960s, a crisis whose incipient shape can be gauged in the celebrated essay The Fire Next Time and the politically urgent play Blues for Mister Charlie (1964). ${ }^{14}$ In what follows, I seek to outline this crisis in One Day, When I Was Lost, while also tracing some of the echoes of Baldwin's engagement with Malcolm in the contemporaneous dialogue with Margaret Mead, A Rap on Race (conducted in 1970, publ. 1971). ${ }^{15}$ These texts help us situate Baldwin and Malcolm in a long line of African-American thinkers of time, a context that has recently been mapped with admirable insight by Daylanne English. In Each Hour Redeem: Time and Justice in African American Literature (2013), she re-reads African-American literary history from Phillis Wheatley to contemporary texts-the experimental plays of Suzan Lori-Parks, the detective fiction of Walter Mosley and Barbara Neely-as a genealogy of negotiations with the difference between the modes of time propounded by the nation's official discourses and the standstills, regressions, stops-and-starts, and uncanny repetitions in which black history, from nadir to nadir, has been lived. ${ }^{16}$

This experience, as English writes, has had a profound influence on black artistic expression: "African American writers, although all too often unacknowledged, have intervened, historically and consistently, in philosophies of time and constructions of citizenship." ${ }^{17}$ By considering the implications of the chronic failure of Enlightenment progressivism in matters of racial justice, the nation's Africandiasporic constituencies have borne witness to the series of betrayals that have delayed and dismissed calls for full citizenship and inclusion. Those who rely on the promise of liberty's forward march have operated under what Martin Luther King, Jr. called "a tragic misconception of time": "the strangely irrational notion that there is something in the very flow of time that will inevitably cure all ills." ${ }^{8}$ Locating an "irrationality" at the very core of "Reason," he argues, in something of an echo of Walter Benjamin, that such political exigencies as gradualism are premised on "a mythical concept of time": "Human progress never rolls in on wheels of inevitability; it comes through the tireless efforts of men willing to be coworkers with God, and without this hard work, time itself becomes an ally of the forces of social stagnation." ${ }^{19}$ In this, black American thinkers and artists have felt the dangerous fraudulence of official proclamations concerning the ethico-political 
ramifications of rational time that European thinkers like Max Horkheimer and Theodor Adorno begun to address mostly after $1945 .^{20}$

Baldwin and Malcolm count as two such chronologists. The most often recognized aspect of their temporal thinking is the rejection of gradualism, the political impatience that King, too, asserts in the title of his 1964 book, Why We Can't Wait. Particularly Malcolm's work is associated with the insistence on immediate action. What is frequently perceived as the radicalness of his politics concerns the exigency of doing justice to the past by acting in the now, of renouncing all deliberation by politicizing impatience: while "others were discussing the past or the future, or a country which may once have existed, or one which may yet be brought into existence," "Malcolm was speaking of the bitter and unanswerable present." 21 When Baldwin writes this in 1972, in the autobiographical essay "No Name in the Street," he is speaking of the chronoethics of "the now," which demands his attention more relentlessly as the losses of the 1960s mount: the moment "invests every action with an impersonal urgency." ${ }^{22}$ Set thine house in order, the child preacher, grown up, tells us; his ethics is the ethics of a decision, of timeliness, especially in the "exceedingly urgent" times of the 1960s. ${ }^{23} \mathrm{He}$ echoes Malcolm: "Anything I do today, I regard as urgent," the latter tells Alex Haley. "No man is given but so much time to accomplish whatever is his life's work." ${ }^{24}$ Both men's temporal sensibilities are marked by finitude, by death's irremediable presence. Living under this pressure, the present tends to contract to its shortest possible unit: that which Baldwin, in A Rap on Race, calls "time now" or "time, now." ${ }^{25}$ Although it is always present in his work, Baldwin begins to insist on this "time now" with an increasing emphasis as the 1960s proceeds. Yet this insistence coincides with his somewhat anxious problematization of the potentially deadening fallout of such nowness. He comes to suggest, paradoxically, that, if time is always now, heeding the present requires the kind of untimeliness that may inform his own indifference to on-time arrivals - and that Malcolm may have discovered as he briefly, toward the end of his life, got to take a breather from the suffocating racial dynamics in his native land.

This essay follows Baldwin's parrying with the ethico-politics of time under the pressures of the increasingly violent crisis, yet another "nadir," in the 1960s. ${ }^{26} \mathrm{I}$ begin by delineating Malcolm's take on the temporalities of modern life in the diaspora, after which we take a brief detour to Richard Wright's Native Son (1940). Like many other thinkers, activists, and artists in the African-American tradition, Malcolm and Wright highlight questions of time in their analyses of diasporic modernity. My main emphasis nevertheless remains on Baldwin's thought, especially as it gets reconfigured in his encounter with Malcolm's work, activism, and assassination. The crisis amidst which their engagement takes place necessitates Baldwin's rethinking of witnessing, the mode of ethicalness that, as I will suggest, demands a temporal (re)orientation. As the calamities of the 1960s escalate, witnessing, the task of the artist, turns into an increasingly problematic stance, the time it takes becoming a lethal luxury. The detached or backward gaze of the artist-witness may be a paralyzing mistake; yet again, one's inability to seek that 
which exceeds the immediately present is no less deadly of a trap. The encounter between Baldwin and Malcolm allows us to outline the evolution of Baldwinian chronoethics in a swiftly changing political context.

\section{Doing Time: Detroit Red's Tutelage}

That the image beneath the clock in Sidney's bar is drawn in pencil may suggest the palimpsestic roles Malcolm assumed during his life and has continued to take after his assassination. Many hands have rubbed out and penciled in their own desire onto his likeness. ${ }^{27}$ Manning Marable has recently-and controversially-assigned this malleability to Malcolm himself. ${ }^{28}$ What Marable calls his self-reinventions take place as a series of temporal readjustments. We find the first of these in his notes on his days as Detroit Red. In the early chapters of his autobiography, Malcolm describes the breathlessness that drives the hustler in his daily existence. Recalling depictions of an industrialized West in literary naturalism and the sociological studies of the Chicago School, the hustler obeys the beat of the present in the urban jungle; it is only his relentless focus on the now that allows him to survive modern life's impersonal forces. Malcolm describes the scene:

Full-time hustlers never can relax to appraise what they are doing and where they are bound. As is the case in any jungle, the hustler's every waking hour is lived with both the practical and the subconscious knowledge that if he ever relaxes, if he ever slows down, the other hungry, restless foxes, ferrets, wolves, and vultures out there with him won't hesitate to make him their prey. ${ }^{29}$

In calling the city a "jungle," Malcolm echoes arguments according to which the uncontrollable forces unleashed by industrialization and urbanization have twisted what the sages of the modern age have designated as modernity's inevitable progress-its "perfectibility," as Hegel and Rousseau call it ${ }^{30}$-into an odd loop that leads us not to the covenanted future but to the primordial past. In figuring this failure of modern futurity in the trope of the "jungle," he echoes Hegel, who locates such primordiality in Africa. For Hegel, Africa constitutes the site of nondialectical stasis, an "unhistorical, undeveloped land."31 Its lack of developmentan inability to take part in the world-historical movement-is the result not only of its permanent stagnation, but also of the uninterrupted rush of its life processes: Africa gives us an existence that "consists of a succession of contingent happenings and surprises." ${ }^{32}$ This paradox was asserted some hundred years after Hegel by another text whose influence on representations of Western modernity cannot be underestimated. In Edgar Rice Burroughs's Tarzan of the Apes (1912), the absence of sapience - the "divine power of reason" - in Africa is explained by the coincidence of "the stillness of the jungle" with "the fastness of the African jungle"; the novel's Western explorers observe "the teeming solitude of that unspeakably quick, yet unthinkably dead, world." 33 The continent's "savage fastness," naming simultaneously a fecund velocity and a paralytic unchangeableness, signals a breach 
in the logic of noncontradiction. ${ }^{34}$ Because of this swift but fixed present, "man as we find him in Africa has not progressed beyond his immediate existence." 35 Consequently, the continent remains outside reason, forever on the "threshold" of history's dialectic.

Aspects of Hegel's and Burroughs's delineations of the nonhuman continent can be found in standard descriptions of modern civilization's discontents. Among these are Malcolm's autobiographical portrayals of his early life, where time, often figured in terms of speeds, constitutes a recurring theme. As Malcolm arrives in Boston, his sister Ella counsels him to "take his time" before getting a job, because "[he] would never again have the time to really see and get to know anything about the city." ${ }^{36}$ She advises her brother to claim the time that is his, to see as much as he can, before, as she knows, the discipline of wage labor will contract the scope of his vision. Yet the time he takes renders Malcolm vulnerable to the "natural lure" of the urban jungle, its life of hustling. ${ }^{37} \mathrm{He}$ eventually gets a job as a shoeshine boy at the Roseland Staten Ballroom, where he learns the basics of urban velocity. At Roseland, his predecessor guides him: “'you got to get a whole lot faster. You can't waste time!"'38 White customers, as his mentor continues, like to see fast black boys: "Just go do it faster . . . Cats tip better, they figure you're knocking yourself out."' ${ }^{39}$ From here on out, Malcolm "practice[s] picking up [his] speed," a discipline whose various modifications the autobiography details. ${ }^{40}$

Like life in Burroughs's Africa, ghetto hustlers necessarily become "fast": swift and stuck. In the urban jungle one has to be "fast at picking up new things"; 41 but such adaptive capacity to newness prevents the kind of invention that many theories of modernity regard as peculiar to the human. Indeed, the intensive immobility of modernity's speed dehumanizes the urbanite, making him "a predatory animal," one of the "tough hyenas and wolves of the street."42 "I had a jungle mind," Malcolm tells his ghost writer, "I was living in a jungle, and everything I did was done by instinct to survive." 43 The autobiography's recurrent word "instinct" indicates this nonhuman temporality: it names a life of full adaptation, which, to become human, the subject must surpass or, as the Freudian science tells us, flunk. Several modern discourses, including psychoanalysis, propose that human time is the time not of instinctual, "fast" adaptations but of terata and exaptions. Many critiques of industrial capitalism consider the worker's alienation from labor the result of life's utilitarianization in the dehumanizing now of industry. Identifying, like Malcolm, urban life with life in the jungle, Max Horkheimer writes in 1967 that industrial labor requires "the kind of mentality that concentrates on the present and can dispense with memory and straying imagination. To find one's way around the jungle of city life with its machinery leaves no time or inclination for anything else." ${ }^{4}$ Baldwin echoes Malcolm and Horkheimer when he writes that urban sites constitute "a howling wilderness," 45 among them New York City, which, as Ida Scott observes in Another Country (1962), counts as "one of the world's great jungles." 46 The speed of events in this jungle prevents the full experiencing of life: Hall Montana in Just Above My Head recalls his youth on the streets, where "life itself-life itself!-depends on timing more infinitesimal than the split 
second, where apprehension must be swifter than the speed of light." ${ }^{47}$ Reason, as Hegel and Rousseau might say, is the casualty: "the pressure of living is too immediate and incessant to allow time for understanding." 48

If racial modernity in the Autobiography closes up the spaces where attention might digress onto the nonpragmatic, the nonpresent, or the nonutilitarian, its dehumanizing pace seems to relinquish its hold on Malcolm in prison. It is here, Baldwin suggests, that Detroit Red's Bildung commences. Malcolm learns to retemporize: he begins to observe a new regime of keeping time, especially as he adopts the discipline that will transform into his work routine for NOI. In the screenplay, Malcolm's fellow inmate Luther urges the young man: "I'll show you how to get out of prison. I'll show you how to be free ... You got to learn not to waste the time, Malcolm. You got to learn how to use the time." ${ }^{49}$ Imagining this exchange, Baldwin takes up Malcolm's autobiographical assertions that, after his stint in prison, a new sense of time imposes itself on him. He describes his time with NOI: "you won't find anybody more time-conscious than I am. I live by my watch, keeping appointments. Even when I'm using my car, I drive by my watch, not my speedometer. Time is more important to me than distance." ${ }^{50}$ His is, Haley observes in the autobiography's epilogue, "an almost fanatical obsession about time." Malcolm tells his ghost writer: "I have less patience with someone who doesn't wear a watch than with anyone else, for this type is not time-conscious . . . In all our deeds, the proper value and respect for time determines our success or failure."'51

Baldwin's screenplay thematizes horology not only in dialogue but also in visuals: the reconfiguring of temporal regimes is evoked in Baldwin's stage directions. During the scene of the burglary that will lead to his arrest, Malcolm's wristwatch "fill[s] the screen with ticking." ${ }^{2}$ The screenplay then bids the camera to cut to an apartment where Malcolm, "stoned out of his head . . looks at the watch":

The watch: which stops ticking.

The watch: being handed back to MALCOLM, over the counter of a repair shop.

The watch: on MALCOLM's arm as he walks, ticking. ${ }^{53}$

The most immediate reference here is to the burglary's initial success, its going off "like clockwork," 54 as well as to the subsequent arrest, which, as we learn from the autobiography, takes place after a stolen watch is identified in the jewelry shop where Malcolm has taken it for repairs. ${ }^{55}$ Yet the cessation of the stolen timekeeper's ticking also suggests the temporal break that Malcolm's prison time will constitute in his life. That his introduction to NOI precipitates time's reordering is further signaled when, beginning to heed Luther's advice, Malcolm acquires a new watch from a pawnshop upon his release from prison. ${ }^{56}$ If Luther, in Baldwin's rendition, weans Malcolm off conking, ${ }^{57}$ he also gifts him a new time, the very time that, I suggest, Martha and Sidney will adopt in Just Above My Head.

Yet, while the Nation of Islam offers Malcolm a life beyond his "survival instincts," the arduous discipline that he develops may not differ in kind from the 
relentlessness with which he describes Detroit Red moving in the urban jungle. If Malcolm Little becomes X by a time reinvention, he begins to be guided by what he calls, perhaps revealingly, his "Muslim instincts." ${ }^{8}$ Malcolm remains "fast," his life "instinctual": the "vehemently non-stop" pace is more consciously adopted in his post-carceral life. ${ }^{59}$ If anything, he learns to play, without changing, the game of racial modernity. In this, his reorientation would have reminded Baldwin of what he unfailingly considers the false epiphany undergone by Bigger Thomas in Native Son. That is, if Bigger models black masculinity for many a subsequent Black Nationalist, we gauge the problems Baldwin detects in Malcolm's post-prison time regime by comparing it to the temporalities that, according to Native Son, speed diasporic modernity.

As much as Detroit Red hustles the streets and does drugs "to kill time," ultimately finding himself in jail with "time on [his] hands," ${ }^{60}$ in Native Son's skywriting scene the unemployed and "restless" Bigger loiters on the streets with "time on his hands." ${ }^{\prime 1}$ The segregated urban environs constitute an informal, but nonetheless effective, prison: as Bigger says to his buddy Gus, "It's just like living in jail."'62 The time that Bigger finds on his hands will turn to the blood that he, under the compulsion of modernity's racial scripts, spills in killing Mary Dalton. It is after the murder that, like Malcolm, Bigger seemingly learns to manipulate the timing of events: always a step ahead, he steers the detectives down wrong paths, skillfully orchestrating the narrative's unfolding around Mary's disappearance. He has, as he boasts in the novel's stage adaptation, "everything figured to the minute."63 Yet modernity's time, as we are told, proves too slippery. Failing to dispose of the evidence in time, he soon finds himself on the lam. As he gazes at a photograph of his employers in a newspaper he has stolen, he anticipates his capture: "Here was a picture of Mr. and Mrs. Dalton standing upon the basement steps. That the image of Mr. and Mrs. Dalton which he had seen but two hours ago should be seen again so soon made him feel that this whole vague white world which could do things this quickly was more than a match for him, that soon it would track him down and have it out with him." ${ }^{34}$ The newspaper is part of modern technologies, whose superior speed is bound to defeat Bigger.

Importantly, as much as Baldwin's Malcolm is given a wristwatch by Luther, Bigger wants to buy a new timekeeper-to replace his "dollar watch" with "a gold one"-as he enters the Daltons' employ. ${ }^{65}$ The time discipline Luther teaches Malcolm may constitute a mere reversal, one whose failure to change the system is illustrated for Baldwin by Native Son's violent dialectics. Bigger realizes for the first time his ability to manipulate racial scripts when he catches his image-his "black face"-in the mirroring surface of a streetcar window. ${ }^{66}$ It is the easy recognizability of his blackface performance as the dumb black boy that renders his deception momentarily so effective. ${ }^{67}$ Similarly, NOI's mythological demonization of whiteness reverses, like a mirror image, the logic of white supremacy. ${ }^{68}$ Put in the terms of Baldwin's chronoethics, the time discipline Malcolm adopts with NOI does not yield anything new but merely binds him more thoroughly in diasporic modernity's temporal regime. Like Bigger, whose game of deception 
demands that he remain relentlessly vigilant in anticipating his enemies' moves, Malcolm keeps a wary eye on the world: "part of him was forever alert," writes one observer. ${ }^{69}$ Thus Malcolm's reformation yields a narrative whose revolutionary promise is quickly compromised. Baldwin's Malcolm notes that, if Luther gave him time, his own activism may have merely helped produce the opulence of his mentor's new wealth, including, importantly, the timekeeper the older man sports: "You wouldn't be wearing that suit, would you, Luther?-How blind I've been! Or that watch."70 This is the timekeeper that compels Martha's attention in Just Above My Head, the chronometer whose syncopation may not, Baldwin suggests, release one from modernity's most familiar habits-just as the ostentatious watch Bigger wants to buy will not allow him to reinvent his life in any meaningful way.

Yet, as Baldwin indicates in One Day, When I Was Lost, Malcolm inhabited his place in the mirror with increasing ambivalence. Toward the end of the screenplay, Luther observes: "Malcolm — the world's much more like me than it is like you. People recognize me. They see me in their mirror. But they don't hardly ever see you. You're not in the mirror with them."71 It is other diasporic locations than those most immediately called "home" that, according to Baldwin but also numerous other commentators, will allow Malcolm to break the mirror, offering him resources for more authentic reinventions of temporality.

\section{Diasporic Time}

The frequently noted contrast between Malcolm and Baldwin-their being, as James Campbell writes, "[t]emperamental and philosophical opposites"-can be posited in temporal terms. ${ }^{72}$ Malcolm lived by the clock, always executing a timely arrival; "I never saw Malcolm late for an appointment," Louis Farrakhan recalls in an interview. "Malcolm was like a clock."73 Baldwin, on the other hand, hardly made it to one meeting on time: he was, as we are told by friends and biographers, chronically late. David Leeming notes that, during his teaching stint at Berkeley in the late 1970s, he was at least an hour late for every single appointment; ${ }^{74}$ according to another biographer, when he would make it to his business meetings on time, he was likely to discover that the appointment had been scheduled for the previous week. ${ }^{75}$

Yet it may not be correct to imply, as Campbell does, that the respective speeds with which Baldwin and Malcolm move constitute each other's "opposites." Baldwin's belatedness is not identical to an insensitivity to time's demands; if his is an "intuitive sense of time ('I know when to leave the party, baby')," on a wholly different calculus than the one Baldwin assigns to Malcolm's political life with the Nation of Islam. His resistance to NOI's time discipline is gauged from the fact that, as he tells us in The Fire Next Time, he was, characteristically, late for his meeting with Elijah Muhammad. ${ }^{77}$

Such resistance to keeping time constitutes an effort to dislodge the time of modernity, the time that we find Malcolm managing not only in the early, hustling days, but also under NOI. Yet the accounts of Malcolm's later life suggest that 
something happened to his temporal regime during his two trips to Africa and the Middle East in 1964. It is on these trips that, "broaden[ing his] scope"-dilating from the relentless now-he distances himself from NOI's Manichean racial theories, while at the same time placing an increasing emphasis on the international context of U.S. civil rights. ${ }^{78}$ In the accounts of these trips, written by himself and others, these changes appear enabled by a further re-temporization, a détente in the unforgiving exigencies of racial modernity. Kevin Gaines gives a characteristic description of Malcolm's time in Ghana: "His travels were an attempt to suspend the passage of time, an attempt to stay aloft, as it were, as long as possible, to sharpen his analysis and enlighten his audiences while evading the political constraints and murderous intrigues that awaited him back in the United States."79 Jan Carew observes: "Malcolm's travels had catapulted him into arenas where the conventional American Black/white obsessions were no longer trapping him in a vortex of rage and hatred. Freed from the psychological entrapment of these pathologies, he had time to review the events of his whole life." ${ }^{\prime 0}$ And Marable writes that, on the second trip, Malcolm pondered the possibility of relinquishing the rigorous regime he had lived under: he takes his cue from the mixture of cultures in Cairo, where life goes on with a "slower pace." 81 This pace is what Malcolm jokingly calls "Arab time!!" in one of his travel diary entries. ${ }^{82}$ It is not that here time simply moves more slowly than in his native country; "Arab time" refers to the incomparable temporization that the narrator of Baldwin's short story “This Morning, This Evening, So Soon” (1960) detects as he walks past Arab cafés in Paris: he finds himself attuning to "the obsessive, stringed music which has no relation to any beat, any time, that [he has] ever known." 83

When Baldwin writes about Malcolm's trips outside the United States, he is thinking of the turning point that his own emigration, in 1948, provided in his temporal negotiations. Speaking to Mead in A Rap on Race, he suggests that, but for his exile, he would have been, like Malcolm under NOI, unable to extricate himself from what he frequently calls America's racial nightmare: "The situation forces you, the black cat in it, to become party to it, whether you like it or not. You cannot escape the pathology of a country in which you're born. You can resist it, you can react to it, you can do all kinds of things, but you're trapped in it." ${ }^{4} \mathrm{He}$ learns what Malcolm does in Africa: to take his time. Speaking of his initial experiences in Paris, he writes that his relocation "taught me things I did not know (how to take a deep breath, for example)." 85 If Malcolm dilates in Africa, Baldwin does so in his exile to Paris, the city where, as he observes, one "ceases, quite, to arrive anywhere on time." ${ }^{66}$ Like Walter Benjamin, who characterizes philosophical thinking as "a continual pausing for breath," ${ }^{87}$ Baldwin, in the breathing space of Paris, finds himself able to think otherwise, which is to say-to eliminate the tautology-to think. In this way, exile enables the expatriate to invent stories other than those that, with racial modernity's inexorable speed, move toward the kinds of foregone conclusions that we find at the end of Bigger's swiftly executed trial. ${ }^{88}$

In his adaptation of Malcolm's autobiography, Baldwin invites us to consider such possibilities for newness, that is, possibilities for time's dilation from the 
unforgiving "nowness" that temporizes the urban jungle of diasporic modernity. This possibility is first embodied in Luther's temporal tutelage; yet his mode of discipline soon finds its limits. The later shift in Malcolm's thinking, upon his experiences abroad, may have reminded Baldwin of the creative and lifesaving space that his own emigration carved out for him. Its promise is exemplified also in Just Above My Head, where Baldwin assigns to Arthur Montana, the narrator's queer gospel singer brother, the emigrant experiences Baldwin himself assumes in his previous autobiographical texts. In Paris, as Hall notes, Arthur "feels free to be an outsider, to watch." ${ }^{99}$ Yet this "watching" is not that of the time discipline whose symbol Malcolm, released from prison, wears on his wrist in One Day, When I Was Lost or that induces Martha to keep a close watch on her timepiece in the novel. Rather, Arthur, like the young Baldwin, is freed from the compelling circuits of racial modernity that bind Detroit Red: if "in New York . . a all his senses were always alert for danger . . . [i]n Paris, he is practically invisible-practically, free." ${ }^{\text {}}$

\section{Time's Witness}

But as much as Arthur gets to "watch" in Paris, exile is, of course, not the end of the story; time, or history, refuses closure, and the breathing space in Europe soon begins to contract. Baldwin's anguish about his distance from the intensifying civil rights struggles in the United States indicates the highly precarious ethical valence of exilic chrononomy. It is particularly in the mid-to-late 1960s texts that he wrestles with the temporal ethics solicited by the decade's escalating brutalities. As he adapts Malcolm's autobiography for the screen, not only are Medgar Evers and Malcolm dead; he receives the news of Martin Luther King, Jr.'s assassination in Hollywood, where he is working on the screenplay. ${ }^{91}$ One Day, When I Was Lost evinces Baldwin's response to these crises: a shift takes place in his chronoethics.

If references to "wristwatch" and "watch" recur in Baldwin's stage directions, the noun itself is ostentatiously verbed in the dialogue. In the scene of Malcolm's famous standoff with the NYPD over the arrest of Johnston Hinton in April 1957, ${ }^{92}$ the police officer who initially refuses the Nation of Islam representatives access to the detainee, looks over Malcolm's partner (and Luther's son) Sidney and asks: "You an eyewitness? You don't look old enough." Sidney replies: “That's because you don't know how soon I started watching you." ${ }^{33}$ It is here that Malcolm's young friend becomes a prototype for the Black Nationalist bartender, his namesake, in Just Above My Head. Continuing the familiar, vigilant watchfulness over white caprice, a survival strategy that we find in black analyses of the nation's racial choreographies from at least the nineteenth century onward, the Sidney of the screenplay has been "watching" - carefully timing - the habits of white power since time immemorial. ${ }^{94}$ If this anticipates the timekeeping that marks Sidney and Martha's new wakefulness, "watching" allows the younger Sidney to claim, to the white policeman's surprise, the authoritative position of an "eyewitness." He knows what time it is.

The exchange between Sidney and the police officer evokes, and places in an explicitly temporal context, one of the most crucial terms in Baldwinian ethics: 
that of witnessing. I've been watching you; I am a witness to your time. Witnessing, as Baldwin frequently writes, is the calling of the artist. The witness-artist embodies memory: he promises to remember, to return, in time, that which otherwise may have passed. His work-watching-is one of temporal record-keeping: he stalls modernity's speed by "describ[ing] things which other people are too busy to describe." ${ }^{\prime 5}$ Baldwin's ethics of witnessing seeks a détente-the thawing of diasporic memory-where the disavowed past would alleviate the defensive focus on the present, the kind of relentlessness with which Detroit Red moves. The witness holds the past open as a realm of potential from which newness can emerge.

The ethical importance of witnessing resides in its prevention of time's usurpation by pragmatic exigencies, if by pragmatism we understand the form of utilitarian forgetfulness that, according to W. E. B. Du Bois's and Richard Wright's occasional critiques of William James, have characterized post-Reconstruction national memory in the United States. ${ }^{96}$ But if Sidney or Baldwin bear witness to the passing of time for both black people, who search for traces of their past in the present, and white people, who insist on agelessness and innocence, watching also exerts a potentially deadly cost. Sidney's vigilance ages him: like Dorian Gray, he is older, more ravaged by time, than his body lets on. He embodies what Baldwin observes elsewhere, the phenomenon of black youth growing old rapidly because of what they have seen during their short lives: "A black person in this democracy is certain to endure the unspeakable and the unimaginable in nineteen years." 7 More recently, Ta-Nehisi Coates, too, has suggested the toll that watchfulness takes on black bodies: "This need to be always on guard [is] an unmeasured expenditure of energy, the slow siphoning of the essence. It contribute[s] to the fast breakdown of our bodies." 98 "One grows up early on my street," as Baldwin put it in 1976. ${ }^{99}$

And, then, in an earlier scene in Baldwin's screenplay, we have a counterpart to the police officer's bemused surprise at the young black man's claim to perception, this time issuing as a white man's appeal for redemptive witnessing. This takes place when the man, whom Detroit Red has escorted to his appointment with a black prostitute, asks that the black youth stay on for the scene of their sadomasochistic play. ${ }^{100}$ Having consented to the man's request, Detroit Red hears the man, being whipped by the woman, cry out: "Is he watching? Oh, watch. Watch. Please ... Oh, watch, watch. Please. Harder. Harder. Harder." ${ }^{101}$ In this scene, Baldwin implies an answer to Malcolm's query, in his autobiography, of "what a psychiatrist would make of" white people's "strange appetites."102 The man's appeal, issuing across the color line with an "unspeakable, despairing, captive avidity,"103 is for a timely rescue from what Wright would call diasporic modernity's quicksand of "fear-guilt." 104 As Baldwin frequently points out, such affects are symptomized in sexual fantasies, in "a bizarre species of guilty eroticism." 105 We should here think not only of the white sheriff in "Going to Meet the Man," but also of Vivaldo Moore in Another Country, who heads for Harlem like so many other whites seeking "life," vital intensity, in the fascinating mirror of blackness. ${ }^{106}$ White Americans' racialized sexuality, no less than their sexualized race consciousness, is frequently lived in sadomasochistic rituals. As one of the characters in If Beale 
Street Could Talk (1974) puts it, with an eminently ambivalent phrasing: “I don't believe there's a white man in this country, baby, who can even get his dick hard, without he hear some nigger moan."' 107 At the same time, as the white john's plea to Malcolm indicates, such suffering, inflicted on the self or the other, is inextricable from Americans' desperate willingness to "believe in black forgiveness." 108 It is in this context that we should read the words of Lyle Britten when, in Blues for Mister Charlie, he asks Richard Henry, the black man who has returned from the North to his southern hometown, to "[p]ardon" him. ${ }^{109}$

But as Richard suggests, such appeals for clemency from the white man constitute only a continuation of the dialectic of sexual-racial fantasies that we find perpetuated in the white john's insistence on a black male witness. In another confrontation with the white southerner, Richard speaks of his lack of interest in continuing the dangerous dance of mutual fascination: "I don't want nothing from you," he tells Lyle. “. . . You can't dance because you've got nobody to dance with-don't you know I've watched you all my life? All my life!" ${ }^{110}$ Like Vivaldo or the unnamed john in the screenplay, white Americans have deposited an idealized innocence onto black people, who thereby become, in the white imaginary, witnesses offering redemption from the existential terrors plaguing the white modern: they give white Americans "time to save themselves." 11 Give me time, the john asks Detroit Red; untangle me from the histories of violence that I compulsively live in my present. Baldwin writes in 1964: "What it means to be a Negro in this country is that you represent, you are the receptacle of and the vehicle of, all the pain, disaster, sorrow which white Americans think they can escape"; "we were," he adds, "the first psychiatrists here." 12 "Sometimes I sing because I'm happy, true, and sometimes I sing because I'm free," Hall Montana echoes in Just Above My Head: "but sometimes I sing because it is so grinding down to spend one's life listening to confessions." 113

The dangers of "watching" are, then, indicated by the shifting uses of our keyword. "Watching" suggests, first, ethical witnessing. In enabling a deceleration, the watchful witness gives others time to broaden their scope, to sharpen their thinking, to see further. Witnessing names, for example, the "watchful attention" with which Malcolm attends to a young sit-in demonstrator, a student with whom he shares a radio show hosted by Baldwin (who is initially afraid of Malcolm "simply eat [ing] the boy alive"). ${ }^{114}$ It offers a secular version of the temporal shelter referenced in the hymn "My Heavenly Father Watches Over Me," which was sung, as Baldwin notes, at MLK's funeral. ${ }^{115}$ It also constitutes the kind of ability for lucid observation that Baldwin assigns to Huey Newton, "always listening and always watching": "Those eyes take in everything, and behind the juvenile smile, he"-much like Sidney in One Day, When I Was Lost-"keeps a complicated scoreboard." 116

Yet "watching," as the work of witnessing, easily slips into-may not be distinguishable from-the exhausting parrying that allows the subject's bare-life survival: it becomes the dehumanizing discipline of watching one's back to whose mastery Sidney confesses; or the internalization of the white gaze urged by the 
southern coworkers of Richard Wright's adolescent autobiographical self in Black Boy (1945): "watch yourself and don't get into trouble." 117 We also find that the position of the witness is inextricable from a lethal passivity: we encounter it in the Little children's helplessness in "watching" their mother's mental deterioration, as well as Malcolm's gloomy prophecy to his audiences about the inevitable smear campaign that will follow his death: "You watch." 118 The term describes the firefighters' murderous neglect in passively "watching" - the word recurs repeatedlythe Littles' house burn down. ${ }^{119}$ Later, Baldwin has Malcolm recall the childhood scene as he witnesses the destruction of his and Betty's home from the firebombing allegedly organized by NOI. "Where are the fire engines?" he asks her, after which we get the following montage:

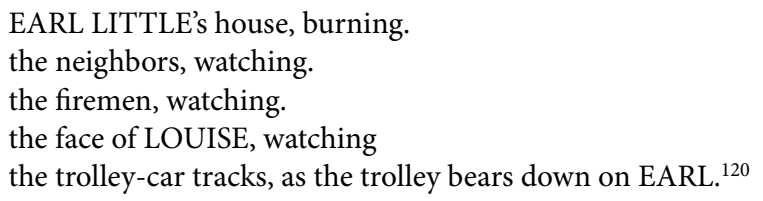

And, finally, the call to the task of "watching" designates the plea for forgiveness, tearfully demanded by white postcolonial melancholic in the throes of his guilty jouissance. ${ }^{121}$ As witnesses, Sidney and Red may either be heading for an early grave or unwittingly offering a fantasy absolution to the white john as diasporic modernity's "fear-guilt" is beaten out of him. If witnessing offers an ethical mode par excellence for much of Baldwin's career, as his engagement with Malcolm's activism and legacy continues, its ambivalent potential in the urgent present becomes increasingly pronounced.

\section{On Time; or, The Law's Delay}

After the string of assassinations of his coworkers and friends in the 1960s, Baldwin feels the pull of the moment in ways that make him question the ethics of witnessing. After so many deaths, he calls himself "the last witness"; but is witnessing enough, he asks, in a letter to his brother in 1970, when "me and mine are being murdered ... in time"? ${ }^{122}$ Witnessing, as he says to Mead, forms a temporal practice: the witness "translate $[\mathrm{s}]$... [w] hat time means." ${ }^{23}$ The witness, as we have said, watches time. In A Rap on Race, Baldwin speaks of "watching [his] children's children discovering, beginning to apprehend that they have been marked by most unfriendly forces. Watching the time, your eyes get heavier or lighter . . "124 In a moment of mortal danger-when "me and mine are being murdered . . . in time"-what is the mode in which witnessing, watching (the) time, can proceed? Whose is the time watching takes? Witnessing may grant one the kind of clarity that characterizes the wakefulness of a convert; but the witness, with heavier eyes, may also find himself paralyzed amidst the oneiric terror-the "tortured dream"that organizes Bigger Thomas's endeavor. ${ }^{125}$ Rather than the relaxation of "taking 
a deep breath" Baldwin had experienced with his 1948 exile, the call may now be for something like the breathlessness that characterizes Detroit Red's focus on the present moment, or the irregularities of breathing that, as Walter Benjamin suggests, not only facilitate thought but may also produce the semi-oneiric hallucinations of someone prone to hyperventilation.

In an aborted sentence, Baldwin tries to explain the dilemma to Mead:

And the fury in me is involved with time now because I have no right-I may be a philosopher, but I have no right-given the situation of this time now, and my role in it, my role in the present ... [He cuts his sentence short; ellipsis in original] On a very serious level, the trap I'm in is that I can't afford the historical point of view. And yet I know something about time present and time now. ${ }^{126}$

As the disintegrating syntax indicates, Baldwin is stymied by a temporal paradox. Feeling the pressure of "time now" he owns the impatience- "I can't afford the historical point of view" - he has attributed to Meridian, Richard Henry's father, in Blues for Mister Charlie. When Parnell James, a white liberal and the editor of the local newspaper, wants to shed light on the racial conflict plaguing the town by exploring the role of class in poor whites' racism, Meridian responds: "For God's sake, spare me the historical view!" 127 The state of emergency that has given birth to Blues for Mister Charlie refuses the complication of subtle readings, the infinite parsing of ethical layers for which Baldwin's own work is often celebrated. Philosophizing takes time, and, as Leo Bersani writes in a different context, "analysis, while necessary, may also be an indefensible luxury." 128 The malignancy of analysis takes root in the waste of time, the "luxury" whose menace Rousseau, for example, locates in the distractive avocations of science. In noting the lethal dangers of "the historical (point of) view," Baldwin repeats modernity's thinkers from Rousseau onward, whose work, intentionally or not, points to an irresolvable aporia in the progressivist hopes of Enlightenment reason. ${ }^{129}$

Like Malcolm X, Baldwin rejected gradualism as the political expression of Enlightenment "perfectibility." In a mid-1980s interview included in the documentary James Baldwin: The Price of the Ticket (1989), he asks:

What is it you want me to reconcile myself to? I was born here almost sixty years ago. I'm not going to live another sixty years. You always told me, "It takes time." It's taken my father's time, my mother's time; my uncles' time, my brothers' and my sisters' time; my nieces' and my nephews' time. How much time do you want for your "progress"? ${ }^{130}$

It is not only that, assuming an infinity of time in which history can be made, progressivism pleads infinite patience-which is to say, stipulates docility; the temporal ideal of perfectibility also renders reason a species of religion, premised on the otherworldliness whose delusive comfort the thinkers of Western Enlightenment proudly pronounced, and continue to pronounce, to have been undone. If Enlightenment, assuming a boundless time in which to resolve antagonisms, is a religion masquerading as secular reason, Baldwin, on the other hand, insists on 
finitude. The temporality of his philosophy is in this sense strictly secular, worldly: his thought never seeks its ethical guarantee elsewhere than in a now of radical immanence. The Enlightenment religion of progress allows an interminable grace period in which the ticket can be redeemed. For Baldwin, there is but the now: the payment is due without delay.

As inheritors of the ideal of "perfectibility," Americans don't believe that "time is real": ${ }^{131}$ their quest for a more perfect union relies on immortality. This is what Giovanni, speaking to David, means when he says of Americans that they "have a funny sense of time-or perhaps [they] have no sense of time at all." "Real" time in American life has been usurped by the teleological faith in the inevitable solution to the world's riddle, familiar from classical Enlightenment philosophy: Americans act, Giovanni continues, "as though with enough time and all that fearful energy and virtue you people have, everything will be settled, solved, put in its place." With time as an endless resource, Americans have withdrawn their belief in "all the serious, dreadful things, like pain and death and love."'132 As existentialism, too, posits, "dread" begins with the shattering of immortality's promise. This dread entails "pain" and "death," but also, Giovanni adds, the possibility of "love." The kind of connectedness and self-transformation that Baldwin calls love is possible only under the sentence of death, only along a "journey to corruption [that] is always, already, half over." ${ }^{133}$ For Baldwin, love is a phenomenon of a finite, corrupt world, the kind whose terror elicits David's hygienic compulsions.

In this world of corruption, death, writes the philosopher Todd May, is "inevitable," but also "uncertain": it will come, but when it does it won't arrive as a telos that yields meaning to what preceded it. Death is unavoidable, yet no achievement. Death's double nature renders the now the time of one's life: "If death is inevitable and uncertain, if it forms no accomplishment, then one might well want to orient oneself toward the present," May suggests. "[T] he lesson of death is that living should focus on the present." 134 Similarly, it is finitude that makes "time now"135 the focal point of Baldwinian ethics. Baldwin unequivocally insists on the fact: "my brothers," he tells Mead, "are not historical figures. They are not going to live forever, any more than you are or I am, and I think one is responsible for those lives." ${ }^{136}$ Malcolm's "urgency," too, comes from his understanding that "any moment of any day, or any night, could bring [him] death." ${ }^{137}$ Put in the most basic terms, "there is no time to waste," for "the whisper beneath [time] is death."138

Yet to think time responsibly one must not move too fast: one must hear, and respond to, in this now more than what is immediately accessible or recognizable. This is the problem that Baldwin grapples with in his descriptions of Malcolm's life: if time cannot be wasted, if it must be contracted to the utilitarian now, one is left with the bare life of survival, which is not a life at all. To live only in the now is a death sentence. Baldwin shares this assumption with much of Western thought: a life, if it is to be human, must entail wastefulness and luxury; it must escape the now. "Man's chief difference from the brutes," William James opines, "lies in the exuberant excess of his subjective propensities-his pre-eminence over them simply and solely in the number and in the fantastic and unnecessary 
character of his wants, physical, moral, æsthetic, and intellectual ... Prune down his extravagance, sober him, and you undo him." 139 The nonhuman, in this imaginary, is marked by instinctual time, by the temporal moment's perfect coincidence with itself: psychoanalysis, for example, makes this argument by contrasting "the immediacy of instincts" to "the inextinguishable duration of desire." 140 Describing the hustlers as foxes, wolves, ferrets, and vultures, Malcolm suggests Detroit Red's dehumanization in the urban jungle, where the time is always now. If the "jungle" tropes Africa, as it does for many Western commentators, Malcolm's point is identical to Hegel's, who posits the continent outside the productively selfcontradictory, porous time of the dialectic. Malcolm intends his autobiography to narrate his successful mobilization, under the Nation of Islam, of a countertime to diasporic modernity's debilitating speed. Yet for Baldwin the time given to the convert doesn't qualitatively differ from the breathless pace of his younger self. Whether hustling in Detroit or agitating in Harlem, Malcolm is gripped by a nonhuman now: he remains a "fast" subject. Without any other time-without time for "a quest for the superfluous"141_ the subject is robbed of his humanity.

It is only in his escape to Africa and the Middle East that Malcolm, according to Baldwin and others, finds the time to recalibrate so as to escape the nonproductive repetition of both the survival discipline in the urban jungle and the race-supremacist mythologies that stall him under NOI. If Hegel finds in "Africa" a nontime-a time without contradiction, perfectly coinciding with itself-for Baldwin "Africa" discloses a time beyond dialectical determinism. In his final novel, he reimagines Malcolm's later life in the former child preacher Julia Miller. Hall Montana encounters his childhood friend after her return from Abidjan, Ivory Coast, the place of her escape from her past of holiness and incestuous abuse by her father. When he asks how long she stayed in Africa, she replies: "About two years. But-putting it that way doesn't really make any sense-you know what I mean? It was some other kind of time." 142 It is the disorientation of an unrecognizable, "other" time that Malcolm, we are told, experienced in "Africa."

The quotation marks around "Africa" are as necessary for Baldwin as they are for Hegel. Describing Julia's time away from the United States, Baldwin joins a long line of Western thinkers, including many black Americans, whose representations of Africa deal in mythologies that obviously-and valuably-tell us more about the speaker's efforts at self-definition than about the object of description. ${ }^{143}$ Julia's character indicates his need, in the post-civil rights United States, to imagine the possibility of an "other kind of time," one unavailable to him in his extant resources.

Malcolm always heeded time's call. In the last scene of One Day, When I Was Lost, the camera, once again, zooms in for a close-up of the wristwatch he wears as he waits to go on stage at the Audubon Ballroom. ${ }^{144}$ Baldwin gleans this detail from Haley. As Haley writes, Malcolm, waiting for the audience to arrive, "kept glancing at his wristwatch," 45 not an unusual tick for a man "like a clock."146 This exacting temporality elicits Baldwin's ambivalence. We have suggested that he expressed his own ethics of (un)timeliness not only in calls for immediate action- "the time is always now"147 - but also in his perennially missed appointments and belated 
arrivals. Marable describes an enraged audience member's greeting to the NYPD officers as they entered the Audubon after the shooting: "Don't hurry," the witness shouts; "come tomorrow." 148 Her mordant words speak of frustration with "the law's delay," the tardiness of official responses to diasporic modernity's chronic violence. ${ }^{149}$ It is this slowness, including the series of betrayed promises in the postReconstruction United States, that, as English demonstrates in Each Hour Redeem, offers a way to understand the thematic emphasis on "time" in African-American letters. Yet if the woman decries the law's belatedness, her words simultaneously express a wish: Please delay: don't hurry; come tomorrow. She cleaves the now: her insistence on timeliness-the sarcastic quip "come tomorrow!" to the copscoincides with a call for a postponement in which "come tomorrow!" functions as a request or an imperative. She not only observes what many black Americans know: that when the law comes, it is likely to deliver a deadly message. Watching time, she also makes a plea for certainty's deferment. "Death ... is uncertain," May writes. "It can come at any time. It might come tomorrow."150 The minimal gap between the moment of iteration and "tomorrow" remains the only breathing space before certainty's arrival. This certainty must be delayed for life not to catch up with itself. Leaning over Malcolm's body, the unnamed woman seeks to sustain an untimely now where death remains in abeyance, arriving later; a now in which to catch one's breath. "I need time," Jan Carew recalls Malcolm saying after the Oxford Union debate on 3 December 1964. "I sensed," Carew continues, "that he was talking about much more than the immediate topic."151 During his trips abroad, time becomes something other than the immediate now whose punctuality Malcolm has chased as Detroit Red and NOI's activist. In One Day, When I Was Lost, Betty Shabazz observes: "when you left this country, you were able to see what you would never have seen if you stayed here." ${ }^{152}$ His vision expands as he detaches his gaze from the immediacies that have colonized his attention.

Yet, ever punctual, Malcolm keeps his appointment: for him, as Marable puts it in the title of chapter 15, even "death comes on time." Another witness of the shooting at the Audubon tells the biographer: "Death ends a thing on time. Whatever may be the instruments to bring it about, when it comes, it comes on time." 153 The living now is untimely; in death we coincide, have caught up, with our moment. That there is no such thing as an untimely death makes the setting, and resetting, of our timekeepers such an urgent task. Baldwin's challenge is to think of an immanent, yet temporally expansive now: one where other times still infect the present moment's singular exigency. It is in the problem's intractability that we find something like the living core of Baldwin's temporal ethics.

\section{Notes}

1 James Baldwin, Just Above My Head, in Later Novels (New York, Library of America, 2015), p. 564.

2 Ibid., pp. 801, 796, 811.

3 Ibid., p. 809. 
4 Ibid., p. 850.

5 Malcolm X and Alex Haley, The Autobiography of Malcolm X (New York, Ballantine, 1992), pp.62-5. For Malcolm, conking signals that "the Negro has completely lost his sense of identity, lost touch with himself"; it is "the emblem of his shame that he is black" (ibid., p.65). For a complication of Malcolm's reading of black urban styles, see Robin G. Kelley, "The Riddle of the Zoot. Malcolm Little and Black Cultural Politics during World War II," in Joe Wood (ed.), Malcolm X: In Our Image (New York, St. Martin's Press, 1992), pp. 155-82.

6 Baldwin, Just Above My Head, pp. 809, 801.

7 Ibid., p. 812.

8 Ibid., p. 810.

9 Quoted in Jan Carew, Ghosts in Our Blood. With Malcolm X in Africa, England, and the Caribbean (Chicago, Lawrence Hill, 1994), p. 83.

10 James Baldwin, The Fire Next Time, in Collected Essays, ed. Toni Morrison (New York, Library of America, 1998), p. 319.

11 James Baldwin, “They Can't Turn Back," in Morrison (ed.), Collected Essays, p. 637. He deploys the phrase also in "A Question of Identity" (1954), when he writes that "one of the most American of attributes [is] the inability to believe that time is real" (James Baldwin, "A Question of Identity," in Morrison [ed.], Collected Essays, p. 99).

12 Chinua Achebe, There Was a Country. A Memoir (New York, Penguin, 2012), p.9.

13 James Baldwin, One Day, When I Was Lost (New York, Laurel, 1992).

14 James Baldwin, Blues for Mister Charlie (New York, Dell, 1964).

15 James Baldwin and Margaret Mead, A Rap on Race (New York, Laurel, 1992). Scant scholarship exists on the screenplay. On its afterlife in Spike Lee's Malcolm $X$ (1992), see D. Quentin Miller, "Lost and ... Found? James Baldwin's Script and Spike Lee's Malcolm X," African American Review, 46:4 (2013), pp.671-85; as well as Brian Norman, "Bringing Malcolm X to Hollywood," in Robert E. Terrill (ed.), The Cambridge Companion to Malcolm X (Cambridge, Cambridge University Press, 2010), pp.39-50; and "Reading a 'Closet Screenplay.' Hollywood, James Baldwin's Malcolm, and the Threat of Historical Irrelevance," African American Review, $391: 2$ (2005), pp. 103-18. Even less scholarly work has been done on the dialogue with Mead: the only substantial discussions I'm aware of are Edward Brathwaite's early reading ("Race and the Divided Self," Caribbean Studies, 14:3 [1974], pp. 127-39) and the brief commentary in Matt Brim, James Baldwin and the Queer Imagination (Ann Arbor, MI, University of Michigan Press, 2014), pp. 170-3.

16 Daylanne K. English, Each Hour Redeem. Time and Justice in African American Literature (Minneapolis, MN, University of Minnesota Press, 2013). Other scholars who have noted the recurrent theme of time in African-American and African-diasporic literatures and cultures include Bonnie J. Barthold, Black Time. Fiction of Africa, the Caribbean, and the United States (New Haven, CT, Yale University Press, 1981); Michael Hanchard, "Afro-Modernity. Temporality, Politics, and the African Diaspora," in Dilip Parameshwar Gaonkar (ed.), Alternative Modernities (Durham, N.C., Duke University Press, 2001), pp.272-98; and Ulfried Reichardt, "Time and the African-American Experience. The Problem of Chronocentrism," Americanstudien/American Studies, 45:4 (2000), pp.465-84. See also my efforts to address the issue: Mikko Tuhkanen, "Out of Joint.' Passing, Haunting, and the Time of Slavery in Hagar's Daughter," American Literature, 79:2 (2007), pp. 335-61; "Native Son and Diasporic Modernity," in Priscilla 
Wald and Michael A. Elliott (eds.), The Oxford History of the Novel in English, vol. 6: The American Novel, 1870-1940 (Oxford, Oxford University Press, 2014), pp.517-29; and "Mankind's Queerest Laboratory'. Richard Wright and the Speed of Decolonization," Obsidian: Literature in the African Diaspora, 11:2 (2010), pp.74-94.

17 English, Each Hour Redeem, p. 22.

18 Martin Luther King, Jr., "Letter from Birmingham Jail," in Why We Can't Wait (New York, Signet, 2000), p. 97.

19 Ibid., p. 99. In "On the Concept of History," Walter Benjamin similarly critiques Marxist theorization of history's "inevitable" movement toward "an infinite perfectibility" ("On the Concept of History," trans. Harry Zohn, in Selected Writings, Vol. 4, ed. Howard Eiland and Michael W. Jennings [Cambridge, MA, Harvard University Press, 2003], $\$ 13$, p.394). Both King and Benjamin address the political ramifications of the Enlightenment belief in progress, an idea to which I return below.

20 Max Horkheimer and Theodor W. Adorno, Dialectic of Enlightenment. Philosophical Fragments, ed. Gunzelin Schmid Noerr, trans. Edmund Jephcott (Stanford, CA, Stanford University Press, 2002).

21 James Baldwin, "No Name in the Street," in Morrison (ed.), Collected Essays, p. 411.

22 Ibid., p. 462.

23 Baldwin and Mead, A Rap on Race, p. 208. Emphasis in original.

24 Malcolm X and Haley, The Autobiography of Malcolm X, p. 435.

25 Baldwin and Mead, A Rap on Race, pp. 159, 174.

26 "Nadir" is Rayford W. Logan's famous characterization of racial relations in postReconstruction, turn-of-the-century United States: Logan, The Betrayal of the Negro from Rutherford B. Hayes to Woodrow Wilson (New York, Collier, new ed., 1965).

27 Baldwin calls Malcolm X "a much disputed legend": "there is, since his death, a Malcolm, virtually, for every persuasion" ("No Name in the Street," p. 426). On these representations, see Wood (ed.), Malcolm X.

28 Manning Marable, Malcolm X. A Life of Reinvention (New York, Viking, 2011). For criticism of Marable's biography, see Jared Ball and Todd Steven Burroughs (eds.), A Lie of Reinvention. Correcting Manning Marable's Malcolm X (Baltimore, MD, Black Classic Press, 2012); and Herb Boyd, Ron Daniels, Maulana Karenga, and Haki R. Madhubuti (eds.), By Any Means Necessary. Malcolm X. Real, Not Invented. Critical Conversations on Manning Marable's Biography of Malcolm X (Chicago, Third World Press, 2012). Marable is not alone in characterizing Malcolm in this way: Barack Obama is similarly impressed by his "repeated acts of self-creation" (Dreams from My Father. A Story of Race and Inheritance [New York, Three Rivers Press, 2004], p. 86); and Ta-Nehisi Coates speaks of his capacity of "always changing, always evolving toward some truth that was ultimately outside the boundaries of his life, his body" (Between the World and $\mathrm{Me}$ [New York, Spiegel and Grau, 2015], p. 48).

29 Malcolm X and Haley, The Autobiography of Malcolm X, p. 126.

30 See Georg Wilhelm Friedrich Hegel, Lectures on the Philosophy of World History. Introduction. Reason in History, trans. H. B. Nisbet (Cambridge, Cambridge University Press, 1984), p. 125; and Jean-Jacques Rousseau, A Discourse on the Origin of Inequality, in The Social Contract and the Discourses, trans. G. D. H. Cole (London, Everyman's Library, 1993), p. 60.

31 Hegel, Lectures on the Philosophy of World History, p. 190.

32 Georg Wilhelm Friedrich Hegel, The Philosophy of History, trans. J. Sibree (New York, 
Dover, 1956), p. 176.

33 Edgar Rice Burroughs, Tarzan of the Apes (New York, Ballantine, 1990), pp.44, 124, 125,60 .

34 Ibid., p. 182.

35 Hegel, Lectures on the Philosophy of World History, p. 177.

36 Malcolm X and Haley, The Autobiography of Malcolm X, p. 48.

37 Ibid., p. 51.

38 Ibid., p. 57.

39 Ibid.

40 Ibid.

41 Ibid., p. 67.

42 Ibid., pp. 155, 248. The ghetto reduces the subject to a state of "[l]iving like an animal[,] thinking like an animal” (ibid., p. 330). The theme repeats: see, e.g., ibid., pp. 104, 105, $118-19,189,301,309,402,429-31$. If not an animal, the dehumanization accomplished by modernity's speed renders the subject an automaton. Working as a Pullman porter, Malcolm observes that the black cooks on the train-the emblem of modernity's speed-“operated like machines" (ibid., p. 84).

43 Haley, epilogue, in Malcolm X and Haley, The Autobiography of Malcolm X, p. 450.

44 Max Horkheimer, Critique of Instrumental Reason, trans. Matthew J. O'Connell et al. (New York, Seabury Press, 1974), p. 22.

45 Baldwin, Just Above My Head, p. 774.

46 James Baldwin, Another Country, in Early Novels and Stories (New York, Library of America, 1998), p. 677.

47 Baldwin, Just Above My Head, p. 527.

48 James Baldwin, "The Harlem Ghetto," in Collected Essays, p. 53.

49 Baldwin, One Day, When I Was Lost, p. 133.

50 Malcolm X and Haley, The Autobiography of Malcolm X, p. 221.

51 Haley, epilogue, p. 444.

52 Baldwin, One Day, When I Was Lost, p. 118.

53 Ibid.

54 Malcolm X and Haley, The Autobiography of Malcolm X, p. 165.

55 Ibid., p. 171.

56 Baldwin, One Day, When I Was Lost, pp.158-9. Apart from the watch, he acquires a new pair of glasses and a suitcase, details that Baldwin adopts from the autobiography (Malcolm X and Haley, The Autobiography of Malcolm X, p.221).

57 Baldwin, One Day, When I Was Lost, pp. 127-8.

58 Malcolm X and Haley, The Autobiography of Malcolm X, p. 342.

59 Baldwin, "No Name in the Street," p. 411.

60 Malcolm X and Haley, The Autobiography of Malcolm X, pp. 145, 179.

61 Richard Wright, Native Son (New York, Perennial, 1993), p. 20.

$62 \mathrm{Ibid}$. The imprisonment of black life by quotidian racism is similarly articulated by Sidney in Just Above My Head as a Black Nationalist insight: "I used to think [my brother] was in prison, and I had to get him out. Now I know we all in prison, and we got to get us out"' (Baldwin, Just Above My Head, p. 814).

63 Paul Green and Richard Wright, Native Son. The Biography of a Young American (New York, Samuel French, 1980), p. 79.

64 Wright, Native Son, p. 224. 
65 Ibid., p. 95. See also English, Each Hour Redeem, p. 37.

66 Wright, Native Son, p. 113.

67 On Bigger's performance, see Mikko Tuhkanen, The American Optic. Psychoanalysis, Critical Race Theory, and Richard Wright (Albany, N.Y., State University of New York Press, 2009), pp. 29-66.

68 This is Marable's argument, too: that Malcolm began to reflect the racialism of American life during his time with NOI became inescapable when, in 1961, he met with the leader of a Ku Klux Klan faction (Marable, Malcolm X, pp. 178-9, 200-1).

69 Carew, Ghosts in Our Blood, p. 36.

70 Baldwin, One Day, When I Was Lost, p. 219.

71 Ibid., p. 254.

72 James Campbell, Talking at the Gates. A Life of James Baldwin (London, Faber and Faber, 1991), pp. 206-7.

73 Quoted in Marable, Malcolm X, p. 121.

74 David Leeming, James Baldwin. A Biography (London, Penguin, 1994), p. 342.

75 Fern Marja Eckman, The Furious Passage of James Baldwin (New York, M. Evans, 1966), pp. 128-9.

76 Ibid., p. 113.

77 Baldwin, The Fire Next Time, p. 322.

78 Malcolm X and Haley, The Autobiography of Malcolm X, p. 416

79 Kevin K. Gaines, American Africans in Ghana. Black Expatriates and the Civil Rights Era (Chapel Hill, N.C., University of North Carolina Press, 2006), p. 180.

80 Carew, Ghosts in Our Blood, p. 45.

81 Marable, Malcolm X, p. 363.

82 Malcolm X, The Diary of Malcolm X (El-Hajj Malik El-Shabazz) 1964, ed. Herb Boyd and Ilyasah Al-Shabazz (Chicago, Third World Press, 2013), p. 98.

83 James Baldwin, "This Morning, This Evening, So Soon," in Early Novels and Stories, p. 875.

84 Baldwin and Mead, A Rap on Race, p. 24.

85 Baldwin, "Notes for The Amen Corner," in The Amen Corner (London, Penguin, 1991), p. 10. In a 1980 speech he similarly recalls: "I went to Paris to get myself together and to take a deep breath" (Baldwin, Conversations with James Baldwin, ed. Fred L. Standley and Louis H. Pratt [Jackson, MS, University Press of Mississippi, 1989], p. 187).

86 Baldwin, "A Question of Identity," p. 93.

87 Walter Benjamin, The Origin of German Drama, trans. John Osborne (London, Verso, 2003), p. 28.

88 Bigger's intuition, in seeing the speed with which modern technology captures and displays his likeness in the newspaper, that his fate is sealed is borne out during the trial, as District Attorney Buckley demands that justice be carried out "without delay"” (Wright, Native Son, p. 407). Urging an immediate death sentence, he drowns out Boris Max's appeals that "More time is needed ..." (ibid., p.415, ellipsis in original). Bigger realizes that the law's precipitate speed has already condemned him. Observing the judge's quick moves-as they return to the courtroom, the defendant does "not have time to sit down before the judge [enters]"-he says to his lawyer: "He's making up his mind too quick. I know I'm going to die"' (ibid., p.416). In rushing ahead to its predetermined outcome, the trial is "but a matter of time, a formality" (ibid., p. 415). The white world secures its defeat of Bigger by the rush to judgment, the temporal squeeze 
that the regime exerts. As Max observes, “sometimes you can't win no matter how you fight; that is, you can't win if you haven't got time"' (ibid., p. 359). The court of law, like the urban jungle (or Hegel's and Burroughs's Africa), gives no time; this no-time marks the inevitability with which we find Bigger's life, like those of many other characters in naturalist novels, recapitulating societal scripts' familiar plotlines.

89 Baldwin, Just Above My Head, p. 925.

90 Ibid.

91 James Baldwin, "The News from All the Northern Cities Is, to Understate It, Grim; the State of the Union is Catastrophic," in The Cross of Redemption. Uncollected Writings, ed. Randall Kenan (New York, Pantheon, 2010), p. 107; Leeming, James Baldwin, pp. 297-8. The effects of MLK's assassination cannot be overestimated. Baldwin alludes to the event twice in his dialogue with Mead. "You see," he notes, "I know my situation is not the same situation I was in when Martin Luther King was alive and when we were trying, when we hoped to bring about some kind of revolution in the American conscience, which is, after all, where everything in some sense has to begin. Of course, that's gone now" (Baldwin and Mead, A Rap on Race, p. 8; see also ibid., p.221). After the assassination, everything "irrevocably altered" (Baldwin, Conversations with James Baldwin, p. 174). See also Baldwin, "No Name in the Street," pp. $357 f f$.

92 On this incident, see Malcolm X and Haley, The Autobiography of Malcolm X, pp. 268-70; and Marable, Malcolm X, pp. 127-9.

93 Baldwin, One Day, When I Was Lost, pp. 173-4.

94 As Baldwin puts it elsewhere, "I have spent most of my life ... watching white people and outwitting them, so that I might survive" ("The Black Boy Looks at the White Boy," in Morrison [ed.], Collected Essays, p.269); the American Negro, he continues, "has had to watch you, outwit you, deal with you, and bear you ... ever since we got here" ("In Search of a Majority. An Address," in Morrison [ed.], Collected Essays, pp. 220-1). Later in the screenplay, in a scene where Malcolm announces the founding of the Muslim Mosque, Inc., Sidney is described as "watching and watchful," a man with "a watchful face" (Baldwin, One Day, When I Was Lost, pp.221, 224). The verb recurs also in Baldwin's 1973 dialogue with Nikki Giovanni, where it articulates a dynamic descriptive of the encounter between Sidney and the police officer: "you watch the man you work for. You have to watch him; you're watching him ... You're watching him. But he's not watching you. He thinks he knows who you are or what you are. You have got to know who he is because your life is in his hands. And you have to watch him because if you don't watch him you might not live from Monday till Tuesday" (James Baldwin and Nikki Giovanni, A Dialogue [Philadelphia, PA, J. B. Lippincott, 1973], p. 21).

95 Quoted in Leeming, James Baldwin, p. 179.

96 On Du Bois and pragmatism, see Shamoon Zamir, Dark Voices. W.E.B. Du Bois and American Thought, 1888-1903 (Chicago, University of Chicago Press, 1995), passim; for Wright's critique, see Wright, introduction, in St. Clair Drake and Horace R. Cayton, Black Metropolis. A Study of Negro Life in a Northern City (New York, Harcourt, Brace, 1945), esp. pp.xxii-xxiii. For other relevant critiques of pragmatism's politics, see John Patrick Diggins, The Promise of Pragmatism. Modernism and the Crisis of Knowledge and Authority (Chicago, University of Chicago Press, 1994); English, Each Hour Redeem, pp. 54-62.

97 James Baldwin, “The Price of the Ticket," in Morrison (ed.), Collected Essays, p. 838. 
98 Coates, Between the World and Me, p. 90.

99 James Baldwin, "A Challenge to Bicentennial Candidates," in Kenan (ed.), The Cross of Redemption, p. 103.

100 For this scene, see Malcolm X and Haley, The Autobiography of Malcolm X, pp. 136-40.

101 Baldwin, One Day, When I Was Lost, p. 100.

102 Malcolm X and Haley, The Autobiography of Malcolm X, pp. 138, 137.

103 Baldwin, "No Name in the Street," p.396.

104 Wright, Native Son, p. 390.

105 Baldwin, "No Name in the Street," p. 412.

106 James Baldwin, "Going to Meet the Man," in Early Novels and Stories, pp.933-50; Baldwin, Another Country.

107 James Baldwin, If Beale Street Could Talk, in Later Novels, p. 444.

108 Baldwin, "No Name in the Street," p. 380.

109 Baldwin, Blues for Mister Charlie, p. 48.

110 Ibid., p. 156.

111 Baldwin, "No Name in the Street," p. 382.

112 Baldwin, "The White Problem," in Kenan (ed.), The Cross of Redemption, pp. 78, 79.

113 Baldwin, Just Above My Head, p. 822.

114 Baldwin, "No Name in the Street," p.410. On this occasion, see also Baldwin, Conversations with James Baldwin, p. 194.

115 Baldwin, "No Name in the Street," pp.449-50.

116 Ibid., pp. 460-1.

117 Wright, Black Boy (American Hunger), in Later Works (New York, Library of America, 1991), p. 181.

118 Malcolm X and Haley, The Autobiography of Malcolm X, pp. 23, 493.

119 Baldwin, One Day, When I Was Lost, pp. 12-13.

120 Ibid., p. 259. For the original scene, see Malcolm X and Haley, The Autobiography of Malcolm X, p. 6 .

121 For this term, whose applicability to the condition of the white American subject I here claim, see Paul Gilroy, Postcolonial Melancholia (New York, Columbia University Press, 2005).

122 Quoted in Leeming, James Baldwin, p.310.

123 Baldwin and Mead, A Rap on Race, p. 158.

124 Ibid., p. 157, ellipsis in original.

125 Wright, Native Son, p. 169.

126 Baldwin and Mead, A Rap on Race, pp. 158-9.

127 Baldwin, Blues for Mister Charlie, p. 60.

128 Leo Bersani, Is the Rectum a Grave? and Other Essays (Chicago, University of Chicago Press, 2010), p. 6.

129 Jacques Derrida offers his groundbreaking assessment of this aporetic structure in $O f$ Grammatology, trans. Gayatri Chakravorty Spivak (Baltimore, MD, Johns Hopkins University Press, 1998).

130 James Baldwin. The Price of the Ticket, dir. Karen Thorsen (Maysles Films and PBS/ American Masters, 1989). This clip is also available on YouTube: see "James Baldwin. How Much Time Do You Want for Your 'Progress'?" https://www.youtube.com/ watch?v=OCUlE5ldPvM (accessed 8 June 2016).

131 Baldwin, “A Question of Identity," p. 99; “They Can’t Turn Back," p. 637. 
132 James Baldwin, Giovanni's Room, in Early Novels and Stories, p. 247.

133 Ibid., p. 223.

134 Todd May, Death (Stocksfield, Acumen, 2009), pp. 100-1.

135 Baldwin and Mead, A Rap on Race, p. 159.

136 Ibid., p. 199.

137 Malcolm X and Haley, The Autobiography of Malcolm X, p. 435.

138 Baldwin, "No Name in the Street," p. 462; Baldwin, Just Above My Head, p. 574.

139 William James, "Reflex Action and Theism," in Writings 1878-1899 (New York, Library of America, 1992), p. 555.

140 Jacques Lacan, "The Situation of Psychoanalysis and the Training of Psychoanalysts in 1956," in Écrits. The First Complete Edition in English, trans. Bruce Fink, in collaboration with Héloïse Fink and Russell Grigg (New York, W.W. Norton, 2006), p. 391.

141 James, "Reflex Action and Theism," p. 555.

142 Baldwin, Just Above My Head, p. 1005.

143 For African-American representations of Africa, see John Cullen Gruesser, "Afro-American Travel Literature and Africanist Discourse," Black American Literature Forum, 24:1 (1990), pp. 5-20; and Black on Black. Twentieth-Century African-American Writing about Africa (Lexington, KY, University of Kentucky Press, 2000).

144 Baldwin, One Day, When I Was Lost, p. 266.

145 Haley, epilogue, p.498. Haley repeats the phrase "glancing at his wristwatch" in consecutive paragraphs; in the latter the "wrist watch" turns from a single-word compound into two words.

146 Quoted in Marable, Malcolm X, p. 121.

147 James Baldwin, "Faulkner and Desegregation," in Collected Essays, p. 214.

148 Quoted in Marable, Malcolm X, p. 441.

149 William Shakespeare, Hamlet, Prince of Denmark, ed. Edward Hubler (New York, Signet, 1987), III.ii.72, p.94. The law's leisurely arrival to Audubon should be contrasted with the swiftness with which the police respond to the emergency call from the white-owned restaurant in New Jersey, where the young Baldwin, as he tells us in "Notes of a Native Son," causes a scene by throwing a glass of water at a waitress: "the police ... arrived ... at once" (Baldwin, "Notes of a Native Son," in Morrison [ed.], Collected Essays, p. 72).

150 May, Death, p. 101. He repeats: "To live in the present is to recognize that the future may not be there, that death could come tomorrow, and therefore that one needs to inhabit the moment as fully as one can" (ibid., p. 105).

151 Carew, Ghosts in Our Blood, p. 82.

152 Baldwin, One Day, When I Was Lost, p. 256.

153 Quoted in Marable, Malcolm X, p. 441.

\section{Works Cited}

Achebe, Chinua, There Was a Country. A Memoir (New York, Penguin, 2012).

Baldwin, James, Another Country (1962), in Early Novels and Stories (New York, Library of America, 1998), pp.361-756.

—The Black Boy Looks at the White Boy" (1961), in Collected Essays, ed. Toni Morrison (New York, Library of America, 1998), pp. 269-85.

_ Blues for Mister Charlie (New York, Dell, 1964). 
"A Challenge to Bicentennial Candidates" (1976), in The Cross of Redemption.

Uncollected Writings, ed. Randall Kenan (New York, Pantheon, 2010), pp. 103-6.

Conversations with James Baldwin, ed. Fred L. Standley and Louis H. Pratt (Jackson,

MS, University Press of Mississippi, 1989).

_ "Faulkner and Desegregation" (1956), in Collected Essays, ed. Toni Morrison

(New York, Library of America, 1998), pp. 209-14.

The Fire Next Time (1963), in Collected Essays, ed. Toni Morrison (New York, Library of America, 1998), pp. 287-347.

Giovanni's Room (1956), in Early Novels and Stories (New York, Library of America, 1998), pp. 217-360.

"Going to Meet the Man" (1965), in Early Novels and Stories (New York, Library of America, 1998), pp. 933-50.

_The Harlem Ghetto" (1948), in Collected Essays, ed. Toni Morrison (New York, Library of America, 1998), pp. 42-53.

- If Beale Street Could Talk (1974), in Later Novels (New York, Library of America, 2015), pp. 363-509.

"In Search of a Majority. An Address" (1960), in Collected Essays, ed. Toni Morrison

(New York, Library of America, 1998), pp. 215-21.

— Just Above My Head (1979), in Later Novels (New York, Library of America, 2015), pp. 511-1039.

"The News from All the Northern Cities Is, to Understate It, Grim; the State of the

Union is Catastrophic" (1978), in The Cross of Redemption. Uncollected Writings, ed. Randall Kenan (New York, Pantheon, 2010), pp.106-7.

"No Name in the Street" (1972), in Collected Essays, ed. Toni Morrison (New York, Library of America, 1998), pp.349-475.

"Notes for The Amen Corner," in The Amen Corner (London, Penguin, 1991), pp. $8-14$.

_Notes of a Native Son" (1955), in Collected Essays, ed. Toni Morrison (New York,

Library of America, 1998), pp.63-84.

- One Day, When I Was Lost (New York, Laurel, 1992).

"The Price of the Ticket" (1985), in Collected Essays, ed. Toni Morrison (New York,

Library of America, 1998), pp. 830-42.

"A Question of Identity" (1954), in Collected Essays, ed. Toni Morrison (New York,

Library of America, 1998), pp.91-100.

“They Can't Turn Back" (1960), in Collected Essays, ed. Toni Morrison (New York,

Library of America, 1998), pp. 622-37.

— "This Morning, This Evening, So Soon" (1960), in Early Novels and Stories (New

York, Library of America, 1998), pp. 865-907.

"The White Problem" (1964), in The Cross of Redemption. Uncollected Writings, ed.

Randall Kenan (New York, Pantheon, 2010), pp.72-9.

Baldwin, James, and Nikki Giovanni, A Dialogue (Philadelphia, PA, J. B. Lippincott, 1973).

Baldwin, James, and Margaret Mead, A Rap on Race (New York, Laurel, 1992).

Ball, Jared, and Todd Steven Burroughs (eds.), A Lie of Reinvention. Correcting Manning Marable's Malcolm X (Baltimore, MD, Black Classic Press, 2012).

Barthold, Bonnie J., Black Time. Fiction of Africa, the Caribbean, and the United States (New Haven, CT, Yale University Press, 1981).

Benjamin, Walter, "On the Concept of History," trans. Harry Zohn, in Selected Writings, 
Vol. 4, ed. Howard Eiland and Michael W. Jennings (Cambridge, MA, Harvard University Press, 2003), pp. 389-400.

The Origin of German Drama, trans. John Osborne (London, Verso, 2003).

Bersani, Leo, Is the Rectum a Grave? and Other Essays (Chicago, University of Chicago Press, 2010).

Boyd, Herb, Ron Daniels, Maulana Karenga, and Haki R. Madhubuti (eds.), By Any Means Necessary. Malcolm X. Real, Not Invented. Critical Conversations on Manning Marable's Biography of Malcolm X (Chicago, Third World Press, 2012).

Brathwaite, Edward, "Race and the Divided Self," Caribbean Studies, 14:3 (1974), pp. 127-39.

Brim, Matt, James Baldwin and the Queer Imagination (Ann Arbor, MI, University of Michigan Press, 2014).

Burroughs, Edgar Rice, Tarzan of the Apes (New York, Ballantine, 1990).

Campbell, James, Talking at the Gates. A Life of James Baldwin (London, Faber and Faber, 1991).

Carew, Jan, Ghosts in Our Blood. With Malcolm X in Africa, England, and the Caribbean (Chicago, Lawrence Hill, 1994).

Coates, Ta-Nehisi, Between the World and Me (New York, Spiegel and Grau, 2015).

Derrida, Jacques, Of Grammatology, trans. Gayatri Chakravorty Spivak (Baltimore, MD, Johns Hopkins University Press, 1998).

Diggins, John Patrick, The Promise of Pragmatism. Modernism and the Crisis of Knowledge and Authority (Chicago, University of Chicago Press, 1994).

Eckman, Fern Marja, The Furious Passage of James Baldwin (New York, M. Evans, 1966).

English, Daylanne K., Each Hour Redeem. Time and Justice in African American Literature (Minneapolis, MN, University of Minnesota Press, 2013).

Gaines, Kevin K., American Africans in Ghana. Black Expatriates and the Civil Rights Era (Chapel Hill, N.C., University of North Carolina Press, 2006).

Gilroy, Paul, Postcolonial Melancholia (New York, Columbia University Press, 2005).

Green, Paul, and Richard Wright, Native Son. The Biography of a Young American (New York, Samuel French, 1980).

Gruesser, John Cullen, "Afro-American Travel Literature and Africanist Discourse," Black American Literature Forum, 24:1 (1990), pp. 5-20.

- Black on Black. Twentieth-Century African-American Writing about Africa (Lexington, KY, University of Kentucky Press, 2000).

Hanchard, Michael, "Afro-Modernity. Temporality, Politics, and the African Diaspora," in Dilip Parameshwar Gaonkar (ed.), Alternative Modernities (Durham, N.C., Duke University Press, 2001), pp. 272-98.

Hegel, Georg Wilhelm Friedrich, Lectures on the Philosophy of World History. Introduction. Reason in History, trans. H. B. Nisbet (Cambridge, Cambridge University Press, 1984).

The Philosophy of History, trans. J. Sibree (New York, Dover, 1956).

Horkheimer, Max, Critique of Instrumental Reason, trans. Matthew J. O'Connell et al. (New York, Seabury Press, 1974).

Horkheimer, Max, and Theodor W. Adorno, Dialectic of Enlightenment. Philosophical Fragments, ed. Gunzelin Schmid Noerr, trans. Edmund Jephcott (Stanford, CA, Stanford University Press, 2002).

James, William, "Reflex Action and Theism," in Writings 1878-1899 (New York, Library of America, 1992), pp. 540-65.

Kelley, Robin D. G., "The Riddle of the Zoot. Malcolm Little and Black Cultural Politics 
during World War II," in Joe Wood (ed.), Malcolm X. In Our Image (New York, St. Martin's Press, 1992), pp. 155-82.

King, Martin Luther, Jr., "Letter from Birmingham Jail," in Why We Can't Wait (New York, Signet, 2000), pp. 85-112.

Lacan, Jacques, "The Situation of Psychoanalysis and the Training of Psychoanalysts in 1956," in Ecrits. The First Complete Edition in English, trans. Bruce Fink, in collaboration with Héloïse Fink and Russell Grigg (New York, W.W. Norton, 2006), pp. 384-411.

Leeming, David, James Baldwin. A Biography (London, Penguin, 1994).

Logan, Rayford W., The Betrayal of the Negro from Rutherford B. Hayes to Woodrow Wilson (New York, Collier, new ed., 1965).

Malcolm X, The Diary of Malcolm X (El-Hajj Malik El-Shabazz) 1964, ed. Herb Boyd and Ilyasah Al-Shabazz (Chicago, Third World Press, 2013).

Malcolm X, and Alex Haley, The Autobiography of Malcolm X (New York, Ballantine, 1992).

Marable, Manning, Malcolm X. A Life of Reinvention (New York, Viking, 2011).

May, Todd, Death (Stocksfield, Acumen, 2009).

Miller, D. Quentin, "Lost and . . Found? James Baldwin's Script and Spike Lee's Malcolm X," African American Review, 46:4 (2013), pp.671-85.

Norman, Brian, "Bringing Malcolm X to Hollywood," in Robert E. Terrill (ed.), The Cambridge Companion to Malcolm X (Cambridge, Cambridge University Press, 2010), pp. 39-50.

_ 'Reading a 'Closet Screenplay.' Hollywood, James Baldwin's Malcolm, and the Threat of Historical Irrelevance," African American Review, 39:1-2 (2005), pp. 103-18.

Obama, Barack, Dreams from My Father. A Story of Race and Inheritance (New York, Three Rivers Press, 2004).

Reichardt, Ulfried, "Time and the African-American Experience. The Problem of Chronocentrism," Amerikanstudien/American Studies, 45:4 (2000), pp.465-84.

Rousseau, Jean-Jacques, A Discourse on the Origin of Inequality, in The Social Contract and the Discourses, trans. G. D. H. Cole (London, Everyman's Library, 1993), pp.31-125.

Shakespeare, William, Hamlet, Prince of Denmark, ed. Edward Hubler (New York, Signet, 1987).

Thorsen, Karen (dir.), James Baldwin: The Price of the Ticket (Maysles Films and PBS/ American Masters, 1989).

Tuhkanen, Mikko, The American Optic. Psychoanalysis, Critical Race Theory, and Richard Wright (Albany, N.Y., State University of New York Press, 2009).

_ "Mankind's Queerest Laboratory.' Richard Wright and the Speed of Decolonization," Obsidian: Literature in the African Diaspora, 11:2 (2010), pp.74-94.

_ "Native Son and Diasporic Modernity," in Priscilla Wald and Michael A. Elliott (eds.), The Oxford History of the Novel in English, Vol. 6: The American Novel, 1870-1940 (Oxford, Oxford University Press, 2014), pp. 517-29.

"'Out of Joint.' Passing, Haunting, and the Time of Slavery in Hagar's Daughter," American Literature, 79:2 (2007), pp.335-61.

Wood, Joe (ed.), Malcolm X. In Our Image (New York, St. Martin's Press, 1992).

Wright, Richard, Black Boy (American Hunger), in Later Works (New York, Library of America, 1991), pp. 1-365.

_ Introduction, in St. Clair Drake and Horace R. Cayton, Black Metropolis. A Study of Negro Life in a Northern City (New York, Harcourt, Brace, 1945), pp. xvii-xxxiv.

- Native Son (New York, Perennial, 1993). 
Zamir, Shamoon, Dark Voices. W.E.B. Du Bois and American Thought, 1888-1903 (Chicago, University of Chicago Press, 1995).

\section{Contributor's Biography}

Mikko Tuhkanen is Associate Professor of English and Africana Studies at Texas A\&M University, where he teaches, among other topics, in African Studies, African-American literature, as well as literary theory and gay and lesbian literature. He is the author of The American Optic: Psychoanalysis, Critical Race Theory, and Richard Wright (2009) and The Essentialist Villain: On Leo Bersani, a forthcoming study, first of its kind, of Bersani's onto-ethics/aesthetics. He is also the editor of Leo Bersani: Queer Theory and Beyond (2014), as well as the co-editor, with E. L. McCallum, of The Cambridge History of Gay and Lesbian Literature (2014) and Queer Times, Queer Becomings (2011). He is currently working on a book-length study of James Baldwin's chronoethics. 